\title{
Green Education: Study on Understanding of Perception and Implementation of Environmentally Friendly Behaviour an IAKN Manado
}

\author{
Agnes Relly Poluan ${ }^{1}$, Nency Aprilia Heydemans ${ }^{2}$, Fienny Maria Langi ${ }^{3}$, \\ Alon Mandimpu Nainggolan ${ }^{4}$ \\ Institut Agama Kristen Negeri (IAKN) Manado, Sulawesi Utara, Indonesia ${ }^{1}$, Institut Agama Kristen Negeri \\ (IAKN) Manado, Sulawesi Utara, Indonesia ${ }^{2}$, Institut Agama Kristen Negeri (IAKN) Manado, Sulawesi Utara, \\ Indonesia ${ }^{3}$, Institut Agama Kristen Negeri (IAKN) Manado, Sulawesi Utara, Indonesia ${ }^{4}$. \\ \{relly.poluan@iakn-manado.ac.id¹, nencyheydemans@iakn-manado.ac.id², fiennylangi@iakn- \\ manado.ac.id ${ }^{3}$, alonmandimpu@iakn-manado.ac.id $\left.{ }^{4}\right\}$
}

\begin{abstract}
Ecological damage on a local scale impacts the global environments. Plastic waste can harm all living things. There needs to be awareness and responsibility to create an ecological based on education system. Green education is an effort to set the mind and behaviour of students in order to contribute to saving the earth from global warming. This study aims to determine the application of the ecology curriculum and understanding of Manado State Christian Religion Institute (IAKN) students about green lifestyle actions. This research uses a qualitative method with a descriptive approach to ecological studies. The data used are observation, documentation, and indepth interviews with the leader of study programs and also the students of IAKN Manado. The result of this study is as follows: Ecological education for students of IAKN Manado needs to be develop and become the part of the process of protecting nature as a friend.
\end{abstract}

Keywords : Curriculum, Ecology, Students, Green Lifestyle.

\section{Introduction}

Plastic waste is an urgent problem for the survival of living things. Indonesia produces 64 million tons / year of plastic waste and is the largest plastic waste producing country in the world after China. The theme of the 2018 world environmental day in the United Nations Environment Program namely the United Nations Environment Program (UNEP 2018) is Beat Plastic Pollution. This theme invites all humans to defeat and control plastic waste. Including the habit of using disposable plastic, and the low awareness of disposing garbage in the trash. Savings, requires awareness from all parties of the threat of environmental damage caused by plastic waste.

Since getting to know plastic in everyday life, humans have always tried to improve the quality of life instantly and practically. In 1862, Alexander Parkes became the first person to introduce plastic as parkesine in London. Then in 1907 plastic was developed by Leo Baekeland in New York with the term bakelite. All of this is inseparable from the field of science and technology which has two sides, namely positive and negative sides. On the positive side, humans use plastic with a practical, lightweight, and strong. On the other hand, the properties of plastics cannot be described in the soil. It takes decades for land and 
hundreds of years for plastic waste to decompose in water. Plastic waste can cause ecological problems.

In the 1950s to 70 s, humans began to produce small amounts of plastic so that plastic waste was relatively easy to manage. Since the beginning of the $1950 \mathrm{~s}$ more than $8,300,000,000$ tons of plastic has been produced, with $60 \%$ plastic ending up in landfills and in nature. In the 1990s, the manufacture of plastic waste has more than tripled in two decades, after a similar increase in plastic production. Since humans are familiar with plastics with various uses such as lightweight, easy to design, practical, low cost, humans are experiencing addictions to the use of disposable plastics. In the early 2000s, plastic waste rose by producing around $300,000,000$ tons of plastic waste annually, equivalent to the weight of the entire human population (Filosofi 2012). It is estimated that in 2025 Indonesia's population will be 327 million people by producing 130,000 tons of plastic waste per day (Puspita 2018).

Various contemporary issues are sweeping people and living things such as: ecological crisis, poverty, terrorism, radicalism and war. All problems come to the attention of the nations of the world and demand efforts to overcome them. Tucker and Grim (2003) explain the ecological crisis affecting all living things. This problem requires a long-term solution to rebuild human and earth relations. Ecological problems are the shared responsibility of all humanity. Because in hekekat human existence and certainty of its future can not be separated from ecological problems (Metzner 2003).

Robert P. Borrong (2003) said that the earth was suffering from illness, thinness, and threatened with death. Emerging global problems facing humanity such as global warming, climate change, floods, landslides, reduced water volume, environmental pollution, loss of a number of species, sinking of coastal settlements due to rising sea levels, and various other problems. This condition causes anxiety for all human beings in the world. In Indonesia the negative impact of using plastic inorganic materials that can be found is that humans use plastic bottles for only 25 minutes but plastic bottles can be decomposed by nature for about 500-1000 years, plastic decomposes 50-100 years, and sterofoam cannot be decomposed land and water (Fhai 2019). This is a serious problem and a joint task to care about ecological issues through minimizing the use of disposable plastics, considering that the effects are very dangerous and can even threaten the entire ecosystem of living things (Wardhana 2004).

Education is a process of changing attitudes and behavior of a person or group of people in an effort to mature humans through teaching and training efforts (KBBI 2002: p. 263). Education is the main pillar of human and community development. Education can produce a new generation that can answer future challenges (Mirsawati 2016). Ecological education is a serious concern for humanity, including in the university environment. Students are expected to not only know the theory but be able to develop it. The importance of ecological education refers to the mutual agreement between the Ministry of Environment and the Ministry of National Education. No. KEP 07 / MEN LH / 06/2005 and No.05 / VI KE / 2005 dated June 3, 2005 with the aim that environmental education be developed through basic environmental concepts that are applied in science education from elementary school up to university (Nurcholis 2017).

Green lifestyle action is a movement to create a healthy, comfortable, clean, beautiful campus environment and can reduce plastic waste (Nasoetion 2016). The campus can be a driving force in the transformation of a green environment. Active participatory citizens have become important targets in research in the 21st century (Laitinen 2018). However, there is still less research that highlights the role of students involved in managing the environment around campus. 
The campus social environment consists of lecturers, education personnel, and students. The campus social environment can affect student enthusiasm for learning. The green lifestyle movements that need to be done such as the use of Google classroom to reduce paper waste and, the use of tumblers as a contribution to reduce plastic bottle waste. Collaboration with the church, government, family and culture is needed for environmentally friendly actions. That way, the campus environment has a responsibility to realize an environmentally friendly campus through a joint commitment to bring the movement to care for the earth as a shared home that needs to be maintained and preserved.

\section{Literrature Review}

The study of students is interesting to study in an ecological approach through green lifestyle actions. This understanding is considered interesting because it can be studied in various paradigms in understanding it. Shima, Ratih Dewi, Mia Wimala and Emma Akmalah (2016) conducted research on the implementation of a green campus at the National Institute of Technology (Itenas), Bandung and launched an educational development program through the Itenas Research Strategic Plan (Renstra) with a commitment to foster an awareness of the importance of style green life in preserving the environment based on Greenmetric UI. Green lifestyle is a habit to live environmentally friendly that is repeated in everyday life (Yuen and Chu 2010). Green lifestyle makes the earth as a friend and not as an object to be exploited and exploited. This activity begins with small actions that can have a big impact such as carrying a tumbler, minimizing tissue and paper, carrying your own bag to reduce plastic waste and carrying food containers (Aviani 2014). Green lifestyle becomes a mirror of one's totality to care about the environment for present and future generations.

In different cases, Irmawati and Jati Waskito (2012) conducted an environmentally friendly lifestyle study through the demographic characteristics of the citizens of Solo. Lifestyle behavior can be influenced through educational factors. Highly educated people are more concerned with the environment than less educated people in reducing the use of plastics and excessive energy consumption. Higher Education is one of the contributions to foster students' understanding from environmental ethics review. This is also described in the admission activities of FISIP Padjadjaran University (Wibowo 2019) to begin the introduction of the campus with a green lifestyle by banning the use of plastic materials once through the Eco-Friendly empathy parcel program aimed at environmentally friendly campaigns. In his opinion, foster a sense of empathy by caring for nature.

Students as agents of transformation need to be equipped with a paradigm of sustainable development. This paradigm is supported by the value of innovation, creative and full of responsibility. Campus as a place of learning for students to find many things and one day they will return to their area of residence. Most students are young people with a dynamic lifestyle. The University of Indonesia's Directorate of Research and Community Service (DRPM UI) in collaboration with the Faculty of Engineering, University of Indonesia (FTUI) carried out campus Environmental Care campaigns (2017) aimed at reducing the use of disposable plastic bottles in the campus environment. This campaign collected 2000 disposable plastic bottles that were exchanged for 200 tumblers. Considering that disposable plastic bottles require 500-1000 years to decompose with nature. The solution, 200 tumblers are distributed and provide mineral water dispensers in the campus environment. At this point, by placing students as agents of transforming green lifestyles on one side, and analyzing 
ecological education with a clean, beautiful and comfortable environment at the campus level, on the other hand, this article is here to fill the void in the realm.

\section{Research Methods}

This study uses a qualitative method through a descriptive approach with the aim of researching, understanding the situation and meaning of a group of people in the present (Sugiyono 2007). This research focuses on students who bring tumblers into learning, sending assignments to google classroom and classroom cleanliness. This has become a green lifestyle for students on campus by building networks with churches and families. This study uses ecological studies to interpret students as subjects. Ecological studies are a method that studies human relations with humans, humans and nature in a cultural, social and economic environment (Zoer'aini 2003). This method leads to the phenomenon of human physical action by placing humans as agents of humane change (Rustandi 2011).

The selection of informants is carried out through a purposive method according to research needs (Creswell 2015). Based on Government Regulation No. 30 of 1990 that students are registered students and study in certain universities. Therefore, the characteristics of the information focused on the head of the IAKN Manado study program and students at the Theology Faculty, the Christian Education Faculty, and the Religious Arts and Social Sciences Faculty. There were four student informants studied, namely: Feronika Sumilat (FS, 19 years) as a semester 1 student in theology faculty, theology study program, Calvin Rantung (CR, 21 years) as a 5th semester student in theology faculty, theology study program, Surya Matialo (SM, 20 years) as a semester 1 student of the Faculty of Arts and Social Sciences of the Religious Psychology Christian Study Program, and Sri Pusut (SP, 21 years) as a Theology Faculty student 5th semester theology study program.

Data collection techniques using observation, documentation and in-depth interviews. Observations were carried out on September 9 to November 15, 2019. The benefits of conducting in-depth interviews were being able to dig up information relating to green lifestyle habits through environmentally friendly activities on campus and dig up ecological curriculum information in each faculty. Through these three data collection techniques, research aims at students as agents of change who have good morals (moral force) that can contribute to dealing with global environmental damage by local action.

\subsection{Ecological Education}

The term of ecology was first introduced by Ernst Haeckel from Germany (1834-1919) who had expertise in biology. Ecology comes from the Greek word oikos, meaning home or place of residence, and logos means knowledge. So, ecology is the study of living things (plants, animals, and humans) to live together in nature through an ecosystem (Jerry 2015). The ecological crisis is caused by the actions of people who are not responsible for nature, such as natural exploitation, hedonistic, materialistic and excessive consumerism. As a result, nature becomes a victim. The phenomenon of global warming and climate change cannot be avoided by all living things. Even suffering and loss are of no value (Susilo 2012).

Efforts to overcome the environmental crisis can be done with education channels. Under the Republic of Indonesia Law No. 20 of 2003 Chapter VI article 13 of education is a conscious and planned effort to realize a learning process that has religious strength, 
knowledge, character, and good skills. The need for human awareness by forming environmentally friendly insights through ecological systems (Chang 2001). Higher Education Support contributes to increasing student awareness and creativity.

Ecological education is an attempt to change student behavior by increasing knowledge, skills and awareness of the current ecological problems. The ultimate goal of ecological education is expected to increase the attitude of responsibility, caring and sensitive to the environment. Until now education in Indonesia is still oriented towards scoring student achievements in the academic field, not yet practicing and developing environmental-based education and entrepreneurial skills. Environmental Education (PLH) which is expected as a vehicle for fostering paradigm changes in the formation of responsible environmental behavior still faces several obstacles. These constraints, among others, there is still an understanding of the meaning of education which is still limited to the "transfer of konwledge", so that mastery of the material is still an important thing compared to changing attitudes let alone changing behavior.

\subsection{Green Lifestyle}

An environmentally friendly lifestyle is formed on the awareness to preserve the environment so that people are more concerned about environmental sustainability. Green lifestyle becomes a lifestyle that needs to be applied by every individual in every day life. Fuchs and Lorek (2005) explain the lack of government commitment against consumerism and high business profits. Regulations are needed to limit the freedom of behavior of people who are not environmentally friendly. Beekman (2004) says that lifestyle refers to the behavior of individuals who spend excessive money and allocate time. In addition, lifestyle according to Hall J. (2007) is a person's lifestyle in daily life with various activities, interests and opinions concerned. Therefore, lifestyle reflects the whole person who interacts with the surrounding environment.

The existence of religion is the basis of a green lifestyle with the understanding that all human activities are God's commands. God as Creator of nature and humans are given the mandate to maintain, manage and preserve the environment according to His orders. Green lifestyle becomes a means to increase faith in Him with a full attitude of responsibility. Managing nature properly and correctly can benefit humanity and environmental preservation that is of higher quality, has a dignity and religious dignity (Sumbawi 2019). So we can say that, the existence of religious values is a foundation, while the green lifestyle is the implementation itself.

\section{Analysis}

The mission of the campus is to minimize environmental damage by increasing the sensitivity of students through ecological education contained in the curriculum. It is hoped that students can become agents of change that can bring about new innovations for the environment. The awareness of environmental care in question is to equip students with ecological education through access to knowledge, specifically being responsible and making a positive contribution to the destruction of nature currently faced. Below are the curriculums in each study program at the Manado State Christian Religion Institute: 
Table 1. Ecology Courses at IAKN Manado

\begin{tabular}{|c|c|c|c|c|}
\hline No. & Faculty & $\begin{array}{c}\text { Study } \\
\text { Program }\end{array}$ & Course & Notes \\
\hline 1 & $\begin{array}{l}\text { Theology } \\
\text { Faculty }\end{array}$ & Theologi & $\begin{array}{l}\text { Environmental } \\
\text { Ethics }\end{array}$ & $\begin{array}{l}\text { Environmental ethics is an elective } \\
\text { course in the 5th and } 7 \text { th semester } \\
\text { considering the dangers of global } \\
\text { warming that occur. The actions of } \\
\text { students caring for the environment } \\
\text { can have an impact on families, } \\
\text { churches and communities or the } \\
\text { movement not to litter. }\end{array}$ \\
\hline 2 & $\begin{array}{l}\text { Theology } \\
\text { Faculty }\end{array}$ & $\begin{array}{l}\text { Pastoral } \\
\text { Counseling }\end{array}$ & $\begin{array}{l}\text { Ecopastoral } \\
\text { Counseling }\end{array}$ & $\begin{array}{l}\text { Ecopastoral counseling is derived } \\
\text { from the formulation of ecology } \\
\text { and compulsory courses in } \\
\text { semester } 4 \text { with the aim of pastoral } \\
\text { counseling caring about the natural } \\
\text { environment that is damaged by } \\
\text { human activity. The impact is } \\
\text { students become creative in making } \\
\text { eco-campus classes by recycling } \\
\text { plastic waste into plastic flower } \\
\text { crafts. }\end{array}$ \\
\hline 3 & $\begin{array}{l}\text { Theology } \\
\text { Faculty }\end{array}$ & Missiology & - & $\begin{array}{l}\text { due to the new study program, it is } \\
\text { actually very important if there is } \\
\text { this course that instills ecological } \\
\text { awareness. Not yet certain in what } \\
\text { semester this course because it } \\
\text { needs to be decided together with } \\
\text { related parties. The hope is students } \\
\text { can become environmental agents } \\
\text { who create new innovations for the } \\
\text { preservation of nature. }\end{array}$ \\
\hline 4 & $\begin{array}{l}\text { Faculty of } \\
\text { Christian } \\
\text { Education }\end{array}$ & $\begin{array}{l}\text { Education } \\
\text { Management }\end{array}$ & $\begin{array}{l}\text { Facility and } \\
\text { Infrastructure } \\
\text { Management }\end{array}$ & $\begin{array}{l}\text { Facilities and infrastructure } \\
\text { management courses include } \\
\text { environmental education which } \\
\text { must be contracted for the } 3^{\text {rd }} \\
\text { semester. It is very important this } \\
\text { course, considering that nature is a } \\
\text { friend of man. The hope: needs to } \\
\text { be taught repeatedly in order to } \\
\text { understand the essence of living in } \\
\text { harmony with nature. }\end{array}$ \\
\hline 5 & $\begin{array}{l}\text { Faculty of } \\
\text { Christian } \\
\text { Education }\end{array}$ & $\begin{array}{l}\text { Christian } \\
\text { education }\end{array}$ & Ecologi & $\begin{array}{l}\text { Ecology courses are urgent, } \\
\text { mandatory as well as important for } \\
\text { Christian scholars (students) to } \\
\text { gain knowledge about the dangers } \\
\text { of global warming for the } \\
\text { environment. Apply knowledge in }\end{array}$ \\
\hline
\end{tabular}




\begin{tabular}{|c|c|c|c|c|}
\hline & & & & $\begin{array}{l}\text { the campus environment by } \\
\text { managing, empowering, } \\
\text { maintaining, preserving and having } \\
\text { environmentally friendly local } \\
\text { wisdom. }\end{array}$ \\
\hline 6 & $\begin{array}{l}\text { Faculty of } \\
\text { Christian } \\
\text { Education }\end{array}$ & Church Music & - & $\begin{array}{l}\text { Other subjects are more urgent to } \\
\text { include in the curriculum which } \\
\text { includes theology, music education } \\
\text { and music skills. }\end{array}$ \\
\hline 7 & $\begin{array}{l}\text { Faculty of } \\
\text { Christian } \\
\text { Education }\end{array}$ & $\begin{array}{l}\text { Early } \\
\text { Childhood } \\
\text { Christian } \\
\text { Education }\end{array}$ & - & $\begin{array}{l}\text { The curriculum for the new study } \\
\text { program is still planned and in the } \\
\text { future it will design ecology } \\
\text { courses. }\end{array}$ \\
\hline 8 & $\begin{array}{l}\text { Faculty of } \\
\text { Religious } \\
\text { Arts and } \\
\text { Social } \\
\text { Sciences }\end{array}$ & $\begin{array}{l}\text { Christian } \\
\text { Psychology }\end{array}$ & - & $\begin{array}{l}\text { Even though it is not in the course, } \\
\text { it will be included in the training } \\
\text { program for students considering } \\
\text { this is a new study program. }\end{array}$ \\
\hline 9 & $\begin{array}{l}\text { Faculty of } \\
\text { Religious } \\
\text { Arts and } \\
\text { Social } \\
\text { Sciences }\end{array}$ & $\begin{array}{l}\text { Sociology of } \\
\text { Religion }\end{array}$ & - & $\begin{array}{l}\text { Not sure yet because this is still a } \\
\text { new study program. But there } \\
\text { should be in the future, such as } \\
\text { social ecology. }\end{array}$ \\
\hline 10 & $\begin{array}{l}\text { Faculty of } \\
\text { Religious } \\
\text { Arts and } \\
\text { Social } \\
\text { Sciences }\end{array}$ & Church Music & - & $\begin{array}{l}\text { This is a new study program and } \\
\text { there are no subjects that talk about } \\
\text { the environment. }\end{array}$ \\
\hline
\end{tabular}

An interesting thing to observe in this research is that not all ecology courses in the academic field develop environmental-based education in the curriculum of study programs at IAKN Manado. Some obstacles were encountered, among others, there were no ecology courses due to new study programs, but in the future there would be courses related to ecology. But on the other hand, there are no ecology courses caused, it is not important for these courses to be included in the church music curriculum, Christian psychology and church music education.

From the problems encountered, the ecology course is not only on understanding the material but there needs to be a change in attitude as agents of transformation. Considering that students not only record various demands about natural damage caused by human activities, but also make the campus in which the learning process shapes students' personal awareness to care for the environment. At this point, the curriculum of study programs in which ecology courses have not yet reached an agreement, impressed in one coin has a different meaning, as business actors as producers carry out subpolitics actively and passively in their subjective interests (Holzer and Sorensen 2003). Likewise, the heads of study programs as leaders run the curriculum actively seeing the urgency of the market according to the needs of students according to their study program. 


\subsection{Ecological Education on Campus as a Green Lifestyle Through Student Narratives}

"I love this nature. The action of loving the environment has been instilled by mothers, such as watering flowers every day, cleaning the house and the hobby of planting trees. I modeled the actions of mothers who are environmentally friendly. Likewise, on the IAKN Manado campus, although during the first semester I had not contracted an ecology course but there were actions and invitations by the lecturer mem Nency, mem Leydi, mner Kristo who taught carrying a tumbler during learning, throwing garbage in the trash, and carrying a handkerchief (FS, 19)".

According to FS that caring for loving the environment grows from the experience of mothers at home then there is self-awareness and invitations from lecturers to be friendly with nature. Together with CR (21 years) has started a simple lifestyle, environmentally friendly by bringing a tumbler, handkerchief and invite his friends to contribute to care for the environment. The benefits of a green lifestyle at IAKN Manado are that the campus becomes clean, healthy, beautiful and the campus residents become comfortable. In addition, the benefits for yourself can live frugally, clean, healthy, and comfortable.

From the explanation above, it is understood that on the one hand, it is necessary to learn from the experience of parents (mothers) who teach life in a friendly manner with nature. On the other hand, it is necessary to be a student who sets an example and is responsible for dealing with the ongoing damage to nature. The role of these students is for the preservation of nature (Tristanto, 2016). In this context, the paradigm shift from an anthropocentrist perspective to a humanist understanding encourages people to act for justice now and for generations to come (Keraf, 2010). It involves stakeholders to minimize global environmental crises and disasters.

According to CR (21 years), how to reduce plastic waste on campus by bringing tumblers and bringing their own food. The reduction of plastic waste has been supported by the campus through the "Anti-Trash Movement" (GAS), received support from the government in the 'clean the world' community and support of the youth program of the Evangelical Church Synod in Minahasa (GMIM) through the use of tumblers and support from the Ambassador North Sulawesi Cloth held a clothing selection event from the remaining plastic waste. Both church and government programs have invited students to have a call to preserve nature with a green lifestyle.

"The action carried out on campus to reduce plastic waste is carrying a tumbler filled with lemon water and bringing your own food. This action is an option and becomes an important requirement. There is an appeal from IAKN Manado, the government and the church by promoting a green lifestyle through reducing and recycling plastic waste. Then, there is awareness after finishing learning to pick up trash in the classroom - CR (21)".

CR said that support from the Manado IAKN campus through lecturers has provided a good example for students. This is a serious contribution that students take part in caring for the earth and nature as part of their faith responsibilities. Regarding campus, government and church programs, CR has a commitment from itself that the action of a green lifestyle. The need for environmentally friendly local actions by building networks to avoid natural disasters and social disasters (Ngelow, 2019).

Meanwhile, Surya Matialo, a student, admitted that students' concern is shown in learning in the Theology Basic Science classes. Tumbler is one of the mandatory rules in class for one semester. This requirement makes students get used to reducing plastic bottle waste. This tumbler carrying activity has been carried out by lecturers and is emulated by students. 
Likewise to minimize the use of paper, independent assignments and group assignments are sent to Google classroom. This action has a positive impact on students at IAKN Manado.

"Every time I enter a class in Basic Theology, I have to bring a tumbler. However, as a student the classic reason arises which is to forget, on borrowed friends and the tumbler breaks. Embarrassed so that the tumbler that was brought into the bag. Water tumblers are usually asked to go to the campus canteen to save money. Then, according to the father's story in the Minahasa culture, drinking water was placed in a coconut shell that had been cleaned. In addition to the tumbler, there is also the challenge of sending Google classroom assignments, which are not having internet data and are lazy to make assignments - SM (20)".

SM understands that as a student there is often a classic reason not to bring a tumbler. For example, forget, the tumbler is borrowed by a friend and broke. Tumbler is put in a bag. This reason is to avoid being embarrassed as a man who often taunts a student friend. According to him, to reduce costs, water was refilled on the canteen campus for free. Although it has become a classroom code, there are still students who are less sensitive to ecology. Solution for using tumbler and google classroom to reduce disposable plastic bottle waste and save paper (Paperless).

Local wisdom emphasizes an environmentally friendly lifestyle. The shell symbol that has been cleaned has become a drinking tool for the Minahasa people told from generation to generation by parents. Shell is an environmentally friendly tool that can be conserved. But unfortunately the use of shell media is rarely used by individual families and for students it is not practical, easy to spill. Local wisdom needs to be preserved even if it is only for domestic use. The need for an environmentally friendly transformation from disposable bottles to multiuse bottles (tumblers).

Meanwhile, Sri Pusut said that there was still lack of self-awareness to bring a tumbler due to forgetfulness, and there was no innovation in environmental care caused by no interest in preserving nature. Bringing a tumbler is just a routine demand from the lecturer that is mutually agreed upon in the classroom. As the following interview quote:

"During my studies at IAKN Manado, there was an order that was mutually agreed upon for being mandatory under lecturers and students namely tumblers. I am often lazy to carry a tumbler because I feel like I am not slang and childish. Until now there has been no innovation made related to the environment. Because there is no interest in preserving the environment. But the activities carried out by lecturers in the classroom based on joint consensus are very good for reducing waste -SP (21)".

According to the SP at each meeting students have implemented the use of a tumbler based on a shared consensus order at the beginning of the 2019 odd semester meeting. He began to realize the importance of ecological education even though there was no innovation he did. There are opportunities in habituation to bring a tumbler, but there is a challenge of forgetting to bring a tumbler on the grounds of not slang and childish. There is a need for strength from oneself to reduce plastic bottle and paper junk.

The main cause of global warming is the human lifestyle that is instant, wasteful, hedonistic, exploitation and environmentally friendly. Rusbiantoro (2008) said there needs to be practical actions that can be taken starting from small activities in our lives every day such as Tiga R, namely Reduce, Reuse and Recycle. That means students must face challenges in themselves by getting used to carrying a tumbler, using a handkerchief, and cleaning the classroom. The second challenge is ridicule from friends on campus that past generations were not modern. The third challenge is that not all study programs program environmental ethics courses in the curriculum. These courses can vary in semesters 3, 4, 5, and 7 according to students' interests and fields. Humans need eight glasses of water per day (Andhini, 2019). 
That's why the second largest disposable plastic bottle waste in the world is consumed by humans. As SP students need to be equipped with an understanding of the green lifestyle on campus. Need to start from yourself, family, campus, church and community which will have a positive impact on the environment on a local scale. Therefore, FS, CR, SM students are implementing global thinking and acting locally where the campus is the driving force for the transformation of a green environment.

\section{Conclusion}

The importance of ecological education as an effort to sensitize students to live environmentally friendly. Ecological problems are a human responsibility that touches on economic, health, social and cultural aspects. The challenges that occur in the field are that not all ecology education-based curricula are applied in study programs. The second challenge relates to a green lifestyle that is the pride of oneself with the reason of forgetting, borrowing friends, children's style and breaking tumblers. But other students understand by carrying a tumbler, sending assignments in google classroom, carrying a handkerchief can be used repeatedly, reducing plastic waste, healthy and save money. Local student strategic action can touch economic, theological, social and cultural aspects. The importance of ecology starts with oneself, then is incorporated into the curriculum with the hope of building joint action through networking between students of the IAKN study program, the church, and the community.

\section{References}

[1] Andhini, Ade Inge. 2019. "Green Lifestyle, Mengurangi Sampah Plastik dengan Tumbler." Diakses dari https://www.ceraproduction.com/publication pada 14 November 2019.

[2] Aviani, Triastuti. 2014. "Penerapan Green Lifestyle di Griya Lembah Keluarahan Abadijaya Kecamatan Sukmajaya Depok Jawa Barat." Skripsi. Universitas Islam Negeri Syarif Hidayatullah.

[3] Beekman V. (2004). "Sustainable Development and Future Generations.” Journal of Agricultural and Environmental Ethics". Vol. 17. No. 1: 3.

[4] Borrong, Robert P. 2003. Etika Bumi Baru. Jakarta : BPK Gunung Mulia.

[5] Cresswell, Jhon W. 2015. Research Design. London: Sage Publication.

[6] Chang, William. 2001. Moral Lingkungan Hidup. Yogyakarta: Kanisius.

[7] Direktorat Riset dan Pengabdian Masyarakat Universitas Indonesia (DRPM UI) bekerja sama dengan Fakultas Teknik Universitas Indonesia (FTUI). 2017. "Aksi UI Peduli Hijau Bye bye Plastic Bottle: Kampanye Gaya Hidup Peduli Lingkungan di Kampus.” Diakses dari http://eng.ui.ac.id/publication pada 10 November 2019.

[8] Fhai. 2019. "12 Jenis Sampah dan Waktu yang Dibutuhkan Terurai." Diakses dari https://www.hipwee.com./publication pada 25 Juli 2019.

[9] Filosofi, Victor Rizal. 2012. "Sejarah Dan Perkembangan Plastik Yang Kini Kian Meyelaputi Dunia Serta Menimbulkan Masalah Lingkungan Yang Komplek." Diakses dari https://Victorwelding.Blogspot.Com/Publication Pada 3 November 2019.

[10] Fuchs D.A. and Lorek S., Sustainable Consumption Governance. (2005). "A History of Promises and Failures", Journal of Consumer Policy. Vol. 28. No. 3: 261.

[11] Hall J. (2007). "The ethical opportunity", Journal of Brand Management. London: May. Vol. 14. No. 5: 365 . 
[12] Holzer, Boris and Mads P. Sorensen. 2003. "Rethinking Subpolitics: Beyond the 'Iron Cage' of Modern Politics?" Theory, Culture and Society, 20 (2), pp. 79-102.

[13] Irmawati dan Jati Waskito. 2012. "Green Lifestyle Warga Kota Solo.” Jurnal Manajemen dan Bisnis, Volume 16, Nomor 1: 47-57.

[14] Jerry, Safril. 2015. "Ekologi dan Konsep Ekosistem." Diakses dari https://www.academia.edu/publication pada 14 November 2019.

[15] Keraf, Alexander Sonny. 2010. Krisis dan Bencana Lingkungan Hidup Global. Yogyakarta: Kanisius.

[16] Laitinen, Hanna. 2018. "Empowering New Agents of Civil Society or Fostering Good Citizens? Framing Youth Participation in Finnish Youth Organization.” Journal of Civil Society 14 (1): 118.

[17] Metzner, Ralph. 2003. Agama, Filsafat \& Lingkungan Hidup, Yogyakarta : Penerbit Kanisius.

[18] Mirsawati. 2016. "Perkiraan Dan Antisipasi Terhadap Masyarakat Masa Depan.” Diakses Dari Https://www.Wawasanpendidikan.com/Publication Pada 4 November 2019.

[19] Nasoetion, P. 2016. "Green Campus Versus Pemanasan Global." Diakses dari https://www.gogreenindonesiaku.com/publication pada 4 November 2019.

[20] Ngelow, Zakaria J. 2019. Teologi Bencana: Pergumulan Iman dalam Konteks Bencana Alam. Jakarta: BPK Gunung Mulia.

[21] Nurcholis Muhammad Tofa. 2017. "Pemanfaatan Game Edukasi Berbasis Android Untuk Pembelajaran Anak Usia Dini Paud Sidoasih.” Jurnal Ilmiah DASI Vol. 18. No. 4: 57-66.

[22] Rusbiantoro, Dadang. 2008. Global Warming for Beginner. Yogyakarta: O2.

[23] Rustandi, Arip. 2011. "Ruang Lingkup Geografi." Diakses dari https://geografiarip.blogspot.com/publication pada 15 November 2019.

[24] Sugiyono. 2007 Memahami Penelitian Kualitatif. Bandung: Alfabeta.

[25] Sumbawi, Syauqi. 2019. "Green Lifestyle dan Religiositas." Diakses dari https://www.kompasiana.com/publication pada 14 November 2019.

[26] Susilo, Rahmad K. Dwi. 2012. Sosiologi Lingkungan dan Sumber Daya Alam. Jogjakarta: ArRuzz Media.

[27] Tristanto, Lukas Awi. 2016. Hidup dalam Realitas Alam: Sketsa-sketsa Ekoinspirasi. Yogyakarta: Kanisius.

[28] Tucker, Mary Evelyn dan John A. Grim. 2003. Agama Filsafat \& Lingkungan Hidup. Yogyakarta: Kanisius.

[29] United Nations Environment Programme (UNEP). 2014. "Our Planet is Drowning in Plastic Pollution" Diakses dari https://www.unenvironment.org/publication pada 30 Oktober 2019.

[30] Wardhana, Wisnu Arya. 2004. Dampak Pencemaran Lingkungan. Yogyakarta: Andi.

[31] Wibowo, Hery. 2019. "Masa Penerimaan Mahasiswa Baru FISIP Unpad Kenalkan Gaya Hidup Hijau.” Diakses dari http://www.unpad.ac.id/publication pada 10 November 2019.

[32] Yuen,T.W. \& Chu, W.W. (2010). "Environmental (green) lifestyles: A survey study in Hong Kong”. Hong Kong: Shue Yan University.

[32] Zoer'aini, D. I. 2003. Prinsip-prinsip Ekologi dan Organisasi. Jakarta: Bumi Aksara. 